\title{
Four transition metal complexes constructed with mixed mercaptotetrazole and 4,4'-bipyridine ligands
}

\author{
Chao-Hong Su $\cdot$ Yu-Kui Wang $\cdot$ Fu-Ping Huang $•$ \\ He-Dong Bian • Qing Yu
}

Received: 21 April 2013/Accepted: 24 June 2013/Published online: 7 July 2013

(C) The Author(s) 2013. This article is published with open access at Springerlink.com

\begin{abstract}
Based on 5-mercapto-1H-tetrazole-1-methanesulfonic acid disodium salt $\left(\mathrm{Na}_{2} \mathrm{mtms}\right)$ and 4,4'-bipyridine (bpy) as ligands, four new transition metal complexes, namely $\left\{\left[\mathrm{Cd}_{2}(\mathrm{mtms})(\mathrm{bpy})_{2}(\mathrm{OAc})_{2}\right] \cdot \mathrm{H}_{2} \mathrm{O}\right\}_{n}(\mathbf{1}),\left\{\left[\mathrm{Cd}(\mathrm{mtms})(\mathrm{bpy})_{2^{-}}\right.\right.$ $\left.\left(\mathrm{H}_{2} \mathrm{O}\right)_{2}\right]_{2} \cdot$ bpy $\left.4 \mathrm{H}_{2} \mathrm{O}\right\}_{n}(2),\left\{\left[\mathrm{Zn}_{2}\left(\mu_{2}-\mathrm{OH}\right)(\mathrm{mtms})(\mathrm{bpy})_{3}\left(\mathrm{H}_{2} \mathrm{O}\right)\right]-\right.$ $\left.\cdot \mathrm{ClO}_{4} \cdot \mathrm{H}_{2} \mathrm{O}\right\}_{n}(3)$, and $\left\{\left[\mathrm{Co}(\mathrm{mtms})_{2}(\mathrm{bpy})\left(\mathrm{H}_{2} \mathrm{O}\right)_{2}\right] \cdot\left[\mathrm{Co}(\mathrm{bpy})_{2^{-}}\right.\right.$ $\left.\left.\left(\mathrm{H}_{2} \mathrm{O}\right)_{4}\right] \cdot \mathrm{H}_{2} \mathrm{O}\right\}_{n}(4)$, have been synthesized and characterized by single-crystal X-ray diffraction. Complex 1 features a pillaredlayer coordination architecture linked by acetate, mtms, and bridging bpy ligands. Complex 2 has a 1D polymeric structure with $\left[\mathrm{Cd}(\mathrm{mtms})(\mathrm{bpy})_{2}\left(\mathrm{H}_{2} \mathrm{O}\right)_{2}\right]$ as the repeating unit; these infinite chains are further connected into a 3D supramolecular framework through $\pi-\pi$ stacking of bpy ligands. In complex $\mathbf{3}$, the mtms ligand combined with $\mu_{2}-\mathrm{OH}$ bridges two $\mathrm{Zn}$ atoms to form a dimer structure, which is different from that of complex 2. Complex 4 shows a 3D supramolecular network containing infinite $\left[\mathrm{Co}(\mathrm{mtms})_{2}(\mathrm{bpy})\left(\mathrm{H}_{2} \mathrm{O}\right)_{2}\right]^{2-}$ anionic chains and free $\left[\mathrm{Co}(\mathrm{bpy})_{2}\left(\mathrm{H}_{2} \mathrm{O}\right)_{4}\right]^{2+}$ cationic components. The luminescence
\end{abstract}

Electronic supplementary material The online version of this article (doi:10.1007/s11243-013-9746-0) contains supplementary material, which is available to authorized users.

C.-H. Su · Y.-K. Wang · F.-P. Huang $(\bowtie) \cdot$ H.-D. Bian ·

Q. Yu (ه)

Key Laboratory for the Chemistry and Molecular Engineering of Medicinal Resources (Ministry of Education of China), College of Chemistry and Chemical Engineering, Guangxi Normal University, Guilin 541004, People's Republic of China e-mail: huangfp2010@163.com

Q. Yu

e-mail: gxnuchem312@yahoo.com.cn properties of $\mathbf{1}$ and $\mathbf{2}$ and the electrochemical properties of $\mathbf{3}$ are reported.

\section{Introduction}

Chemical templates have an important role in the formation of complexes containing multiple components that have defined structural assemblies [1, 2]. Several previous studies have shown that geometries and sizes of ligands, the coordinating ability of anions, and the nature of metals are all important in determining the structures of such complexes [3-8]. $\mathrm{N}$-heterocycles with sulfhydryl ligands are capable of $-\mathrm{N}(\mathrm{H})$ $\mathrm{C}(=\mathrm{S}) \leftrightarrow-\mathrm{N}=\mathrm{C}(-\mathrm{SH})$ tautomerization. Heterocyclic nitrogen can participate in coordination, while the sulfhydryl moiety can be used as a bridging group [8-14]. The soft sulfhydryl group has good coordination ability, because it has empty $3 d$ orbital that can accept electrons from the metal [8, 14-16]. Recently, research into nitrogen heterocycles with sulfhydryl ligands has mainly concentrated on sulfhydryl imidazole, sulfhydryl-(1,2,4)-triazole, and sulfhydryl tetrazole [8, 14, 17-19]. In our previous studies, we have reported some novel coordination polymers with 5-mercapto-1H-tetrazole-1-acetic acid [17]. In addition, bis- or multidentate ligands based on bipyridine (bpy) are outstanding bridging ligands, and a number of frameworks have been synthesized [20, 21]. Normally, 4,4'-bpy is an effective rodlike linker joining metal atoms for propagation of coordination networks $[14,21,22]$.

Herein, we present four transition coordination polymers containing mtms (Scheme 1) and bpy (Scheme 2) coligands, namely $\left\{\left[\mathrm{Cd}_{2}(\mathrm{mtms})(\mathrm{bpy})_{2}(\mathrm{OAc})_{2}\right] \cdot \mathrm{H}_{2} \mathrm{O}\right\}_{n} \quad$ (1), $\left\{\left[\mathrm{Cd}(\mathrm{mtms})(\mathrm{bpy})_{2}\left(\mathrm{H}_{2} \mathrm{O}\right)_{2}\right]_{2} \cdot \mathrm{bpy} \cdot 4 \mathrm{H}_{2} \mathrm{O}\right\}_{n}(\mathbf{2}),\left\{\left[\mathrm{Zn}_{2}\left(\mu_{2}-\mathrm{OH}\right)-\right.\right.$ $\left.\left.(\mathrm{mtms})(\mathrm{bpy})_{3}\left(\mathrm{H}_{2} \mathrm{O}\right)\right] \cdot \mathrm{ClO}_{4} \cdot \mathrm{H}_{2} \mathrm{O}\right\}_{n}(\mathbf{3})$, and $\left\{\left[\mathrm{Co}(\mathrm{mtms})_{2}-\right.\right.$ (bpy) $\left.\left.\left(\mathrm{H}_{2} \mathrm{O}\right)_{2}\right] \cdot\left[\mathrm{Co}(\text { bpy })_{2}\left(\mathrm{H}_{2} \mathrm{O}\right)_{4}\right] \cdot \mathrm{H}_{2} \mathrm{O}\right\}_{n}$ (4). 
Scheme 1 The four coordination modes of mtms ligand observed in this work
Scheme 2 The five coordination modes of bpy ligand observed in this work<smiles>[M]O[SH](=O)(Cn1nn[n+]([M])c1S[M])O[M]</smiles>

( I )<smiles>[M]Sc1n(CS(=O)(=O)O)nn[n+]1[M]</smiles>

(III)<smiles>[M]N1C=CC(c2cc[n+]([M])cc2)=CC1</smiles>

(I)<smiles>[Y13][n+]1ccc(-c2cc[n+]([BH])cc2)cc1</smiles>

(III)<smiles>[M]Sc1nnnn1CS(=O)(=O)O</smiles>

(II)<smiles>[M][n+]1nnn(CS(=O)(=O)O)c1S</smiles>

( IV)<smiles>[M][n+]1ccc(-c2ccncc2)cc1</smiles>

(II)<smiles>[2H][13c]1ccc(-c2ccncc2)cc1</smiles>

(IV)

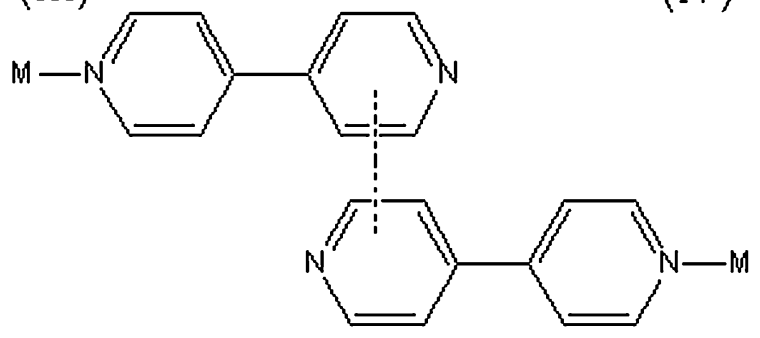

(V)

\section{Experimental}

\section{Materials and measurements}

All reagents were commercially available and used without further purification. Elemental analyses for C, H, N, and S were carried out with a Perkin-Elmer 2400II elemental analyzer. IR spectra were recorded on a Perkin-Elmer Spectrum One FTIR spectrometer with $\mathrm{KBr}$ pellets in the range $4,000-400 \mathrm{~cm}^{-1}$. Electrochemical measurements were made at room temperature using a BAS Epsilon electrochemical workstation with a conventional threeelectrode cell consisting of a glassy carbon working electrode, a platinum auxiliary, and a saturated calomel reference electrode $(\mathrm{SCE}) . \mathrm{KCl}\left(0.1 \mathrm{~mol} \mathrm{~L}^{-1}\right)$ was used as a supporting electrolyte in aqueous solution.

Synthesis of complex $\mathbf{1}$

Bipyridine (77.8 mg, $0.5 \mathrm{mmol}$ ) was added to a stirred solution of $\mathrm{Na}_{2} \mathrm{mtms} \quad(120.6 \mathrm{mg}, \quad 0.5 \mathrm{mmol})$ and $\mathrm{Cd}(\mathrm{OAc})_{2} \cdot 2 \mathrm{H}_{2} \mathrm{O}(274.0 \mathrm{mg}, 1 \mathrm{mmol})$ in a mixture of $15 \mathrm{ml}$ (1:1) $\mathrm{H}_{2} \mathrm{O} / \mathrm{EtOH}$. The mixture was stirred under reflux for $3 \mathrm{~h}$ and then filtered. After a month, colorless block crystals were obtained from the filtrate. Yield: $60 \%$. Anal. Calc. for $\mathrm{C}_{26} \mathrm{H}_{26} \mathrm{Cd}_{2} \mathrm{~N}_{8} \mathrm{O}_{8} \mathrm{~S}_{2}(\%)$ : C, 36.0; H, 3.2; N, 12.9; $\mathrm{S}, 7.4$. Found (\%): C, 36.0; H, 3.4; N, 12.7; S, 7.2. IR (KBr, $\left.\mathrm{cm}^{-1}\right)$ : 3,432(w), 1,603(w), 1,567(w), 1,414(w), 1,288(s), 
1,220(w), 1,183(m), 1,075(m), 1,046(w), 1,007(s), 807(m), $630(\mathrm{~m})$.

\section{Synthesis of complex 2}

The synthesis of colorless block crystals of $\mathbf{2}$ followed the same procedure as for 1 , except that $\mathrm{Cd}(\mathrm{OAc})_{2} \cdot 2 \mathrm{H}_{2} \mathrm{O}$ was replaced by $\mathrm{Cd}\left(\mathrm{ClO}_{4}\right)_{2} \cdot 6 \mathrm{H}_{2} \mathrm{O}$. Yield: $50 \%$. Anal. Calc. for $\mathrm{C}_{54} \mathrm{H}_{60} \mathrm{Cd}_{2} \mathrm{~N}_{18} \mathrm{O}_{14} \mathrm{~S}_{4}$ (\%): C, 42.2; H, 3.9; N, 13.7; S, 8.3. Found (\%): C, 42.3; H, 3.8; N, 13.4; S, 8.5. IR $\left(\mathrm{KBr}, \mathrm{cm}^{-1}\right)$ : 3,391(m), 1,601(w), 1,532(s), 1,490(s), 1,411(w), 1,399(m), 1,371(s), 1,355(m), 1,271(w), 1,249(m), 1,226(w), 1,180(w), 1,047(w), 1,006(s), 806(w), 629(m).

\section{Synthesis of complex $\mathbf{3}$}

The preparation of $\mathbf{3}$ was similar to $\mathbf{1}$, but using $\mathrm{Na}_{2} \mathrm{mtms}$ (120.6 mg, $\quad 0.5 \mathrm{mmol}), \quad \mathrm{Zn}\left(\mathrm{ClO}_{4}\right)_{2} \cdot 6 \mathrm{H}_{2} \mathrm{O} \quad(372.4 \mathrm{mg}$, $1 \mathrm{mmol}), \mathrm{H}_{2} \mathrm{O}(10 \mathrm{~mL}), \mathrm{CH}_{3} \mathrm{OH}(5 \mathrm{~mL})$, and bpy (155.6 mg, $1 \mathrm{mmol})$. After 3 days, pale yellow block crystals were obtained. Yield: $55 \%$. Anal. Calc. for $\mathrm{C}_{33} \mathrm{H}_{35} \mathrm{ClN}_{10} \mathrm{O}_{11} \mathrm{~S}_{2}$ $\mathrm{Zn}_{2}$ (\%): C, 40.5; H, 3.6; N, 14.3; S, 6.6. Found (\%): C, 40.4; H, 3.9; N, 14.2; S, 6.4. IR (KBr, $\left.\mathrm{cm}^{-1}\right)$ : 3,427(w), 1,611(w), 1,596(w), 1,535(m), 1,489(s), 1,416(w), 1,389(m), 1,319(s), 1,216(w), 1,187(w), 1,105(w), 1,046(w), 1,016(m), 807(w), 642(m).

\section{Synthesis of complex 4}

Complex 4 was prepared by a similar procedure as described for 1, using $\mathrm{Na}_{2} \mathrm{mtms}$ (120.6 mg, $\left.0.5 \mathrm{mmol}\right), \mathrm{Co}(\mathrm{N}-$ $\left.\mathrm{O}_{3}\right)_{2} \cdot 6 \mathrm{H}_{2} \mathrm{O}$ (145.5 mg, $\left.0.5 \mathrm{mmol}\right)$, bpy (155.5 mg, $1 \mathrm{mmol}$ ), $15 \mathrm{ml}(2: 1) \mathrm{H}_{2} \mathrm{O} / \mathrm{EtOH}$, and five drops of DMF. Red block crystals were obtained after 14 days. Yield: $61 \%$. Anal. Calc. for $\mathrm{C}_{34} \mathrm{H}_{48} \mathrm{Co}_{2} \mathrm{~N}_{14} \mathrm{O}_{16} \mathrm{~S}_{4}(\%)$ : C, 35.4; H, 4.2; N, 17.0; S, 11.1. Found (\%): C, 35.1; H, 4.2; N, 17.1; S, 11.4. IR $\left(\mathrm{KBr}, \mathrm{cm}^{-1}\right)$ : 3,411(w), 1,656(m), 1,629(m), 1,535(s), 1,492(s), 1,413(w), 1,390(s), 1,373(m), 1,293(m), 1,259(s), 1,238(w), 1,189(w), 1,068(m), 1,043(w), 813(m), 629(m).

\section{X-ray crystallography}

Diffraction data were collected on a Bruker Smart CCD diffractometer with graphite-monochromated Mo-K $\alpha$ radiation ( $\lambda=0.71073 \AA)$ at $298 \mathrm{~K}$. The structures were solved by direct methods and refined by full-matrix least squares on $F^{2}$ using SHELXL-97 [23]. All non-hydrogen atoms were refined anisotropically. Hydrogen atoms were positioned geometrically and refined by a riding mode. The crystallographic data for 1-4 are listed in Table 1. Selected bond lengths and angles are listed in Table $2 \uparrow$ in the Supplementary Information.

\section{Results and discussion}

\section{Crystal structure of complex $\mathbf{1}$}

As shown in Fig. 1a, complex 1 exhibits a dimeric structure in which two $\mathrm{Cd}$ atoms are bridged by two acetates; one adopts syn-syn mode $\left(\mu_{2}, \eta^{2}\right.$-carboxylato), and the other coordinates through one $\mathrm{O}$ atom $\left(\mu_{2}, \eta^{1}\right.$-carboxylato), which is different to other previously reported binuclear $\mathrm{Cd}(\mathrm{II})$ complexes [24]. The Cd...Cd distance is $3.9462 \AA$. Cd1 and Cd2 adopt octahedral coordination geometries. $\mathrm{Cd} 1$ is coordinated by three $\mathrm{O}$ atoms from two acetates, and three $\mathrm{N}$ atoms from two bpy ligands and one mtms ligand. $\mathrm{Cd} 2$ is ligated by two $\mathrm{N}$ atoms from two bpy ligands, two $\mathrm{O}$ atoms from two acetate anions, plus one $\mathrm{O}$ atom and one $\mathrm{S}$ atom from an mtms ligand. The mtms acts as a tridentate-bridging ligand (Scheme 1, mode I) to link adjacent dimeric $\mathrm{Cd}$ (II) units, generating a 1D zigzag infinite chain. The adjacent $\mathrm{Cd}$-mtms chains are further connected into a 2D pillared-layer architecture by bridging-bpy ligands along the $a c$ plane (Scheme 2, mode I) (Fig. 1b). Finally, complex 1 forms a supramolecular 3D network through intermolecular hydrogen bonds [O8-8C $\cdots$ O6 = 2.848(16) $\mathrm{A}, \quad$ O8-H8B $\cdots \mathrm{O} 2 \mathrm{~A}=2.788(19) \AA$ ] (symmetry code: $A: x+1 / 2,-y+3 / 2, z+1 / 2$ ) (Fig. $1 \mathrm{c} \dagger$ ). The relevant hydrogen bond parameters are summarized in Table $3 \uparrow$.

Crystal structure of complex 2

Complex $\mathbf{2}$ was synthesized in a similar way as for $\mathbf{1}$, except that $\mathrm{Cd}(\mathrm{OAc})_{2} \cdot 2 \mathrm{H}_{2} \mathrm{O}$ was replaced by $\mathrm{Cd}\left(\mathrm{ClO}_{4}\right)_{2} \cdot 6 \mathrm{H}_{2} \mathrm{O}$. However, complex 2 shows a linear, infinite $1 \mathrm{D}$ polymeric structure with a neutral component $\left[\mathrm{Cd}(\mathrm{mtms})(\mathrm{bpy})_{2}\left(\mathrm{H}_{2} \mathrm{O}\right)_{2}\right]$ as the repeating unit (Fig. 2a), which is quite different from complex $\mathbf{1}$. The $\mathrm{Cd}$ atom is in a distorted octahedral geometry, with three $\mathrm{N}$ atoms from three bpy ligands, two $\mathrm{O}$ atoms from two coordinated water ligands, and one $\mathrm{S}$ atom from an mtms ligand. The mtms ligand adopts an S-bonding monodentate coordination mode (Scheme 1, mode II), and the tetrazole ring is on the outside, as also found in our previously reported mercaptotetrazole complexes $\left[\mathrm{Cd}\left(\mathrm{mtz}_{2} \mathrm{Br}_{2}\right] \quad(\mathrm{mtz}=1-[2-(\mathrm{N}, \mathrm{N}-\right.$ dimethylamino-ethyl]-5-mercapto-1H-tetrazole) [8] and $\left\{\left[\mathrm{Co}^{\mathrm{III}}(\mathrm{mmtz})_{2}(1,10 \text {-phen })_{2}\right] \cdot \mathrm{NO}_{3}\right\} \quad(\mathrm{mmtz}=1-$ methyl-5mercapto-tetrazole [14]. Of the bpy ligands in complex 2 , one adopts a terminal coordination mode to link $\mathrm{Cd}(\mathrm{II})$ forming $\left[\mathrm{CdN}_{3} \mathrm{O}_{2} \mathrm{~S}\right]$ units (Scheme 2, mode II), while the other acts as a spacer to bridge the $\left[\mathrm{CdN}_{3} \mathrm{O}_{2} \mathrm{~S}\right]$ units, leading to $1 \mathrm{D}$ infinite chains along the $\mathrm{b}$ axis (Scheme 2, mode I). These $1 \mathrm{D}$ chains are further connected into a 3D supramolecular framework through $\pi-\pi$ stacking interactions from the free neutral bpy ligands (Scheme 2, mode V) and hydrogen bonds among the bpy ligands (Scheme 2, 
Table 1 Crystal data and structure refinement summary for complexes 1-4

\begin{tabular}{|c|c|c|c|c|}
\hline Complex & 1 & 2 & 3 & 4 \\
\hline Empirical formula & $\mathrm{C}_{26} \mathrm{H}_{26} \mathrm{Cd}_{2} \mathrm{~N}_{8} \mathrm{O}_{8} \mathrm{~S}_{2}$ & $\mathrm{C}_{54} \mathrm{H}_{60} \mathrm{Cd}_{2} \mathrm{~N}_{18} \mathrm{O}_{14} \mathrm{~S}_{4}$ & $\mathrm{C}_{33} \mathrm{H}_{35} \mathrm{ClN}_{10} \mathrm{O}_{11} \mathrm{~S}_{2} \mathrm{Zn}_{2}$ & $\mathrm{C}_{34} \mathrm{H}_{48} \mathrm{Co}_{2} \mathrm{~N}_{14} \mathrm{O}_{16} \mathrm{~S}_{4}$ \\
\hline Formula weight & 867.51 & $1,538.24$ & 978.02 & $1,155.00$ \\
\hline Crystal system & Monoclinic & Monoclinic & Monoclinic & Triclinic \\
\hline Space group & $C c$ & $C c$ & $P 2(1) / c$ & $P-1$ \\
\hline$a(\AA)$ & $11.7124(12)$ & $24.426(3)$ & $14.7772(12)$ & $10.1567(11)$ \\
\hline$b(\AA)$ & $16.6543(15)$ & $11.90640(13)$ & $10.4334(19)$ & $11.5085(12)$ \\
\hline$c(\AA)$ & $17.160(2)$ & $24.025(3)$ & $26.390(3)$ & $12.2008(15)$ \\
\hline$\alpha\left({ }^{\circ}\right)$ & 90.00 & 90.00 & 90.00 & $111.215(2)$ \\
\hline$\beta\left({ }^{\circ}\right)$ & $107.439(2)$ & $115.269(2)$ & $95.004(2)$ & $102.207(1)$ \\
\hline$\gamma\left({ }^{\circ}\right)$ & 90.00 & 90.00 & 90.00 & $99.766(1)$ \\
\hline Volume $\left(\AA^{3}\right)$ & $3,193.4(6)$ & $6,318.5(10)$ & $4,053.2(9)$ & $1,251.1(2)$ \\
\hline$Z$ & 4 & 4 & 4 & 1 \\
\hline Calculated density $\left(\mathrm{Mg} / \mathrm{m}^{3}\right)$ & 1.804 & 1.617 & 1.603 & 1.533 \\
\hline Reflections collected & 8,001 & 15,916 & 19,921 & 6,510 \\
\hline Independent reflections & $5,621[R(\mathrm{int})=0.056]$ & $8,743[R($ int $)=0.0340]$ & $7,143[R$ (int $)=0.0476]$ & $4,413[R($ int $)=0.054]$ \\
\hline Data/restraints/parameters & $4,881 / 9 / 417$ & $8,743 / 2 / 830$ & $7,143 / 0 / 590$ & $4,299 / 3 / 319$ \\
\hline Goodness of fit on $F^{2}$ & 1.03 & 1.055 & 1.017 & 1.00 \\
\hline Final $R$ indices $[I>2(I)]$ & $\begin{array}{l}R_{1}=0.0593 \\
w R_{2}=0.1031\end{array}$ & $\begin{array}{l}R_{1}=0.0345 \\
w R_{2}=0.0700\end{array}$ & $\begin{array}{l}R_{1}=0.0450 \\
w R_{2}=0.0977\end{array}$ & $\begin{array}{l}R_{1}=0.0737 \\
w R_{2}=0.1733\end{array}$ \\
\hline$R$ indices (all data) & $\begin{array}{l}\mathrm{R}_{1}=0.0915 \\
w R_{2}=0.1122\end{array}$ & $\begin{array}{l}\mathrm{R}_{1}=0.0487 \\
w R_{2}=0.0780\end{array}$ & $\begin{array}{l}\mathrm{R}_{1}=0.0915 \\
w R_{2}=0.1233\end{array}$ & $\begin{array}{l}R_{1}=0.1229 \\
w R_{2}=0.1994\end{array}$ \\
\hline
\end{tabular}
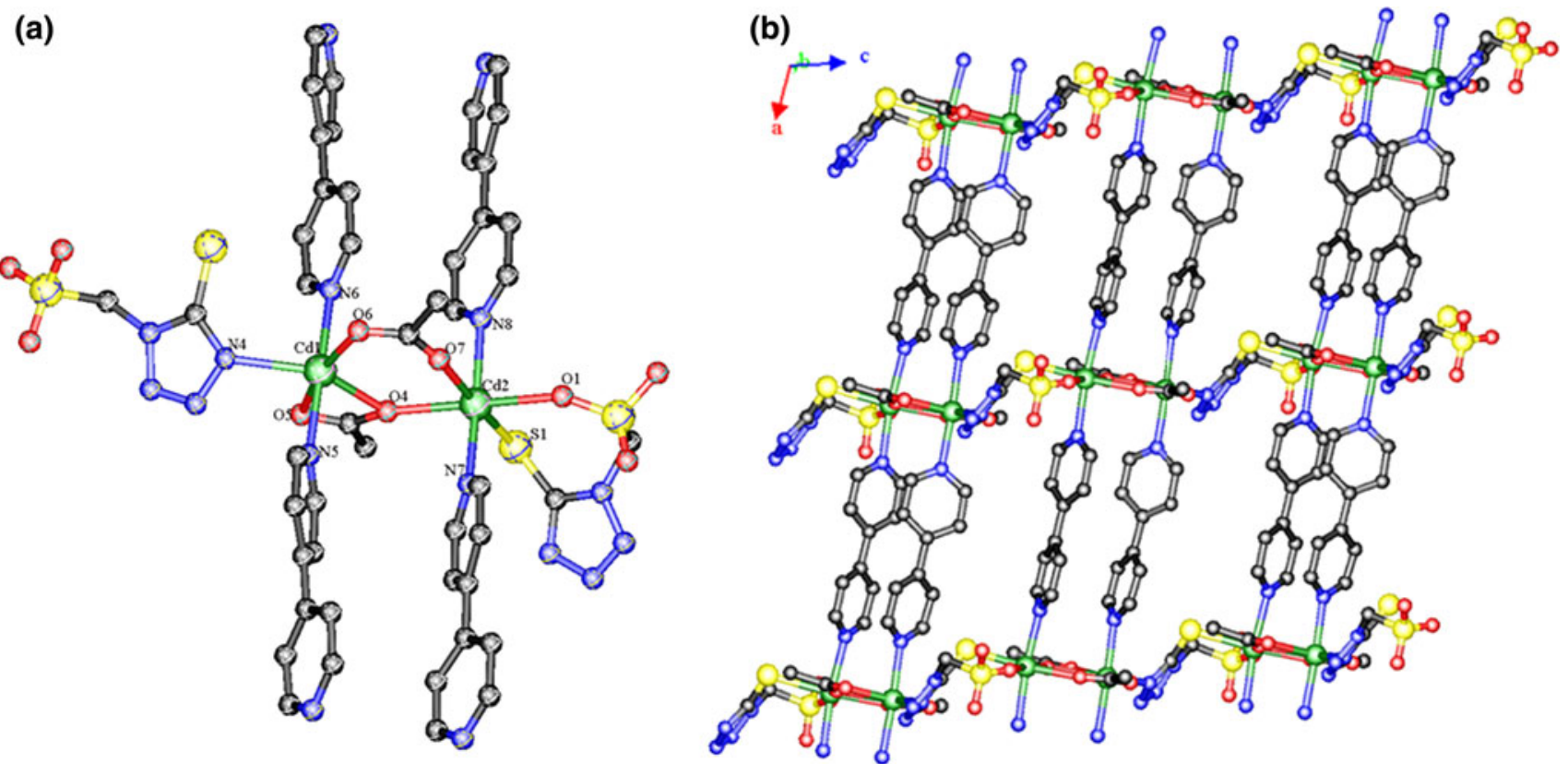

Fig. 1 a View of the coordination environment of the Cd(II) center in 1. Symmetry codes: $A: x,-y+1, z+1 / 2$. b View of the 2D pillaredlayer of 1 along the ac plane. Symmetry code: $(A) x+1 / 2,-y+3 / 2, z+1 / 2$

mode III, IV), coordinated water, and the uncoordinated O atom of the mtms ligand (Fig. $2 b \dagger$ ). In short, the bpy ligands play an important role in forming the structure of $\mathbf{2}$, revealing five different coordination modes.
Crystal structure of complex 3

Use of $\mathrm{Zn}\left(\mathrm{ClO}_{4}\right)_{2} \cdot 6 \mathrm{H}_{2} \mathrm{O}$ instead of $\mathrm{Cd}\left(\mathrm{ClO}_{4}\right)_{2} \cdot 6 \mathrm{H}_{2} \mathrm{O}$ gave complex 3, whose structure with $P 2(1) / c$ space group is 


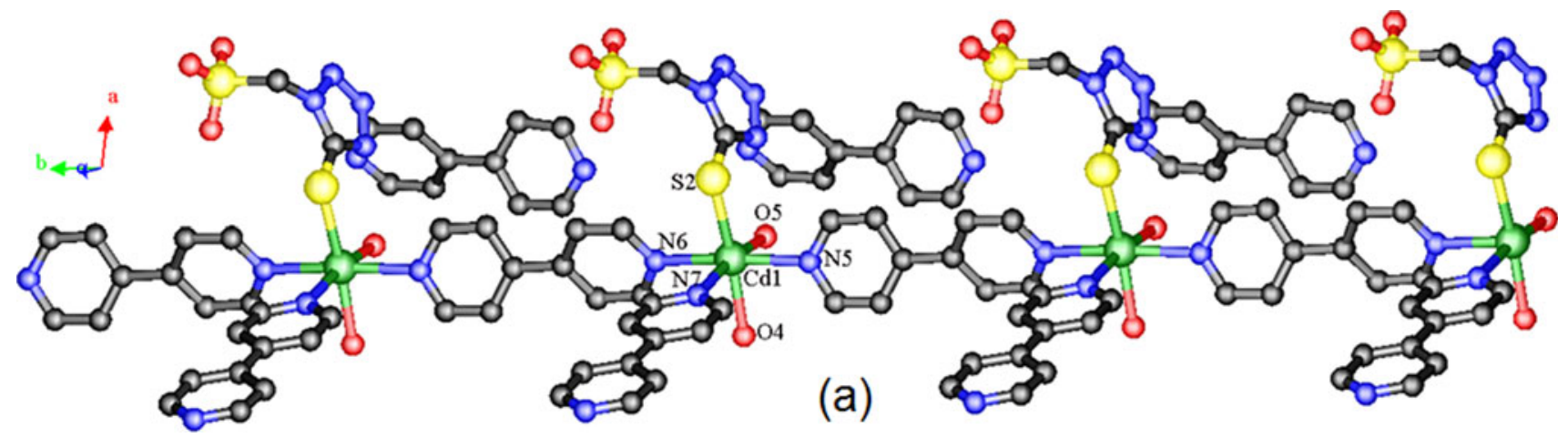

Fig. 2 a View of the 1D infinite chain of 2 along the $b$ axis. Symmetry codes: $A: x, y-1, z$

different from that of complex 2. In complex 3 (Fig. 3a), the bidentate-bridging mtms ligand (Scheme 1, mode III) combines with an $\mu_{2}-\mathrm{OH}$ bridge between two $\mathrm{Zn}$ atoms to form a binuclear unit. The coordination environment of $\mathbf{3}$ shows a butterfly-like structure, in which four bpy ligands act as the wings, while the mtms ligand is located at the head. $\mathrm{Zn} 1$ is surrounded by two bpy ligands, one mtms ligand, one coordinated water ligand, and one hydroxy ligand to form a distorted trigonal-bipyramidal geometry. The axial positions are occupied by $\mathrm{N} 4$ and $\mathrm{O} 5$ with an $\mathrm{N} 4-\mathrm{Zn} 1-\mathrm{O} 5$ bond angle of $174.12(13)^{\circ}$. While $\mathrm{Zn} 2$ is in a distorted tetrahedral coordination geometry provided by one hydroxy, one mtms, and two bpy ligands. The $\mathrm{Zn}-\mathrm{N}$ bond distances range from 2.022(4) to 2.215(4) $\AA$, and the $\mathrm{Zn}-\mathrm{S}$ bond distance is $2.3215(16) \AA$, which are similar to other complexes [23, 24]. The binuclear units link each other by bpy ligands (Scheme 2, mode I, II) to form a 1D zigzag chain along the c axis. The most important interchain interaction in the crystal packing is hydrogen bonds among uncoordinated $\mathrm{ClO}_{4}{ }^{-}$, coordinated hydroxy, coordinated water, free water, the uncoordinated sulfonic group of $\mathrm{mtms}$, and the bpy ligand (Scheme 2, mode III) (Fig. $3 b \dagger$ ). Compared to the similar coordination modes of bpy in complexes $\mathbf{2}$ and $\mathbf{3}$, the architecture of $\mathbf{3}$ is more complicated. The tetrazolyl- $\mathrm{N}$ of $\mathrm{mtms}$ can provide potential coordination sites, and uncoordinated $\mathrm{ClO}_{4}{ }^{-}$ anion may also help to determine the final coordination architectures.

\section{Crystal structure of complex 4}

As illustrated in Fig. 4a, complex 4 contains two components, namely $\left[\mathrm{Co}(\mathrm{mtms})_{2}(\mathrm{bpy})\left(\mathrm{H}_{2} \mathrm{O}\right)_{2}\right]^{2-}$ and $[\mathrm{Co}(\mathrm{b}-$ py) $\left.{ }_{2}\left(\mathrm{H}_{2} \mathrm{O}\right)_{4}\right]^{2+}$ ions. Atom $\mathrm{Co} 1$ is located on a crystallographic inversion center and octahedrally coordinated by two mtms $\mathrm{N}$ atoms and two bpy $\mathrm{N}$ atoms in the equatorial plane, plus two coordinated water ligands in the axial positions, with an $\mathrm{O} 4-\mathrm{Co} 1-\mathrm{O} 4 \mathrm{~A}$ bond angle of $180.0^{\circ}$. The coordination environment of $\mathrm{Co} 2$ is provided by two bpy $\mathrm{N}$ atoms in the axial positions, with four coordinated water ligands in the equatorial plane. The Co2-N bond distances range from 2.179(6) to 2.203(5) $\AA$, which are comparable with other complexes [25].

The structure of the complex anion $\left[\mathrm{Co}(\mathrm{mtms})_{2}(\mathrm{~b}-\right.$ py) $\left.\left(\mathrm{H}_{2} \mathrm{O}\right)_{2}\right]^{2-}$ is the same as that of our previously reported complex $\left[\mathrm{Co}^{\mathrm{II}}(\mathrm{mmtz})_{2}\left(4,4^{\prime}-\text { bpy }\right)\left(\mathrm{H}_{2} \mathrm{O}\right)_{2}\right]_{n} \quad(\mathrm{mmtz}=1-$ methyl-5-mercapto-tetrazole) [14]. The mtms acts as a N-bonding monodentate ligand (Scheme 1 , mode IV). The bpy spacers bridge adjacent Co1 atoms to generate a 1D chain along the $\mathrm{b}$ axis (Scheme 2, mode II). The bpy ligands adopt terminal coordination mode (Scheme 2, mode I) to link $\mathrm{Co} 2$ centers, forming the cationic complex $\left[\mathrm{Co}(\text { bpy })_{2}\left(\mathrm{H}_{2} \mathrm{O}\right)_{4}\right]^{2+}$. These $\mathrm{Co} 2$ components are vertically penetrating into the $1 \mathrm{D}$ chains of $\mathrm{Co}$, showing a rail-like structure (Fig. 4d). The supramolecular structure mainly depends on the $\pi-\pi$ stacking of bpy (Scheme 2, mode V), and intermolecular hydrogen bonds among the water ligands, the uncoordinated sulfonic group of the mtms ligand, and the bpy ligand (Scheme 2, mode III).

Photoluminescence properties

It is well known that $\mathrm{Cd}(\mathrm{II})$ complexes can exhibit interesting luminescence properties $[8,24]$. The solid-state luminescence of the free $\mathrm{Na}_{2} \mathrm{mtms}$ ligand and complexes 1 and $\mathbf{2}$ was investigated at room temperature and is shown in Fig. $5 \uparrow$. $\mathrm{Na}_{2} \mathrm{mtms}$ shows an emission peak at $460 \mathrm{~nm}$ when excited at $301 \mathrm{~nm}$. Upon excitation at $304 \mathrm{~nm}$, complexes 1 and 2 display emission maxima at 353 and $362 \mathrm{~nm}$, respectively, which are both greatly blue-shifted compared to the free $\mathrm{Na}_{2} \mathrm{mtms}$ ligand. Since the $\mathrm{Cd}$ (II) center has $d^{10}$ electronic configuration, the emissions of complexes $\mathbf{1}$ and 2 can be tentatively assigned to ligand-to-metal charge transfer (LMCT) [26-28]. These complexes may be suitable as blue-light-emitting materials, since they show luminescence in the blue region [29]. 


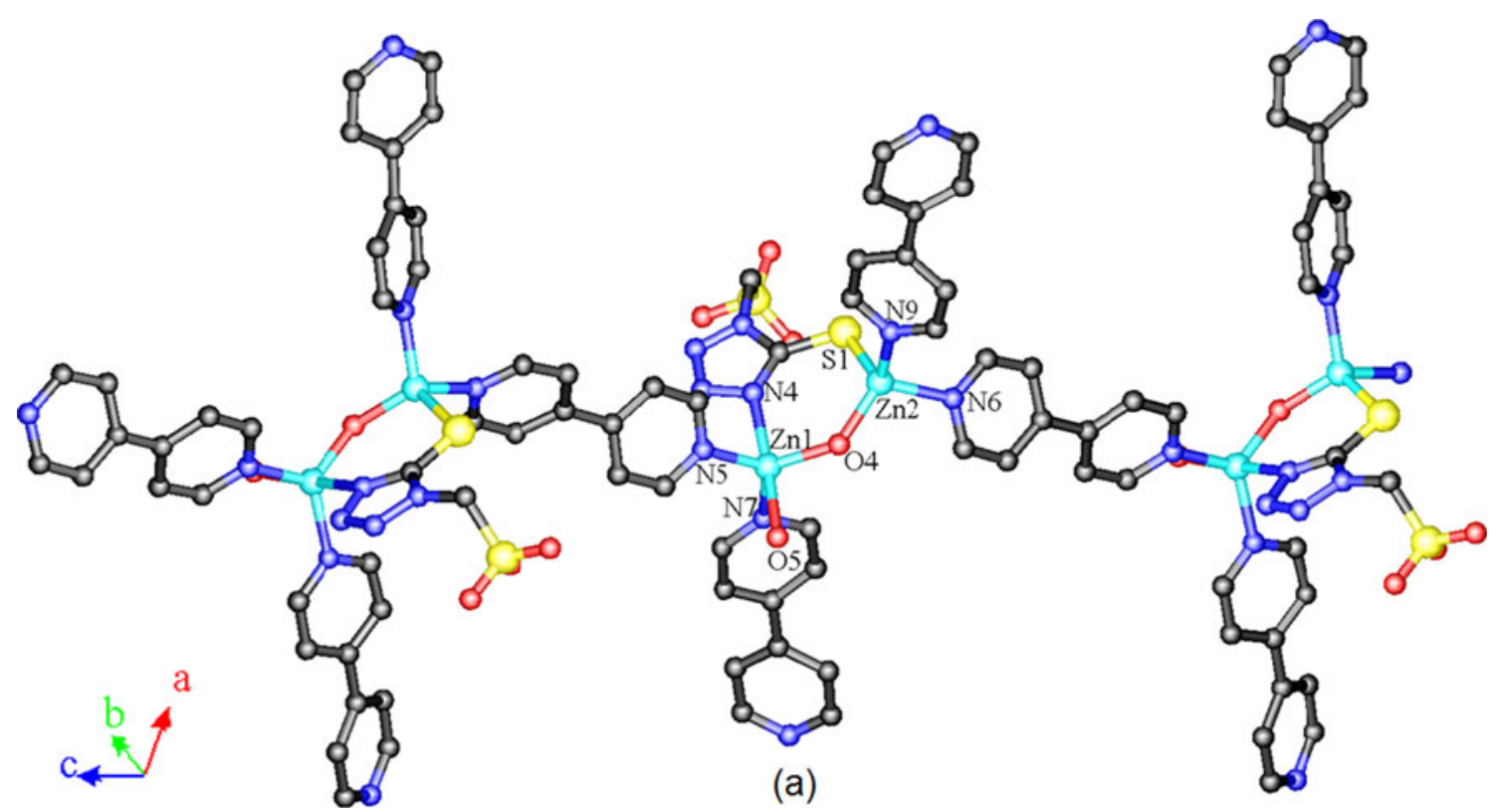

Fig. 3 a 1D infinite chain of 3 along the $c$ axis. Symmetry codes: $(A) x, y-1, z ;(B) x+1, y, z ;(C)-x+1, y+1 / 2,-z+5 / 2$
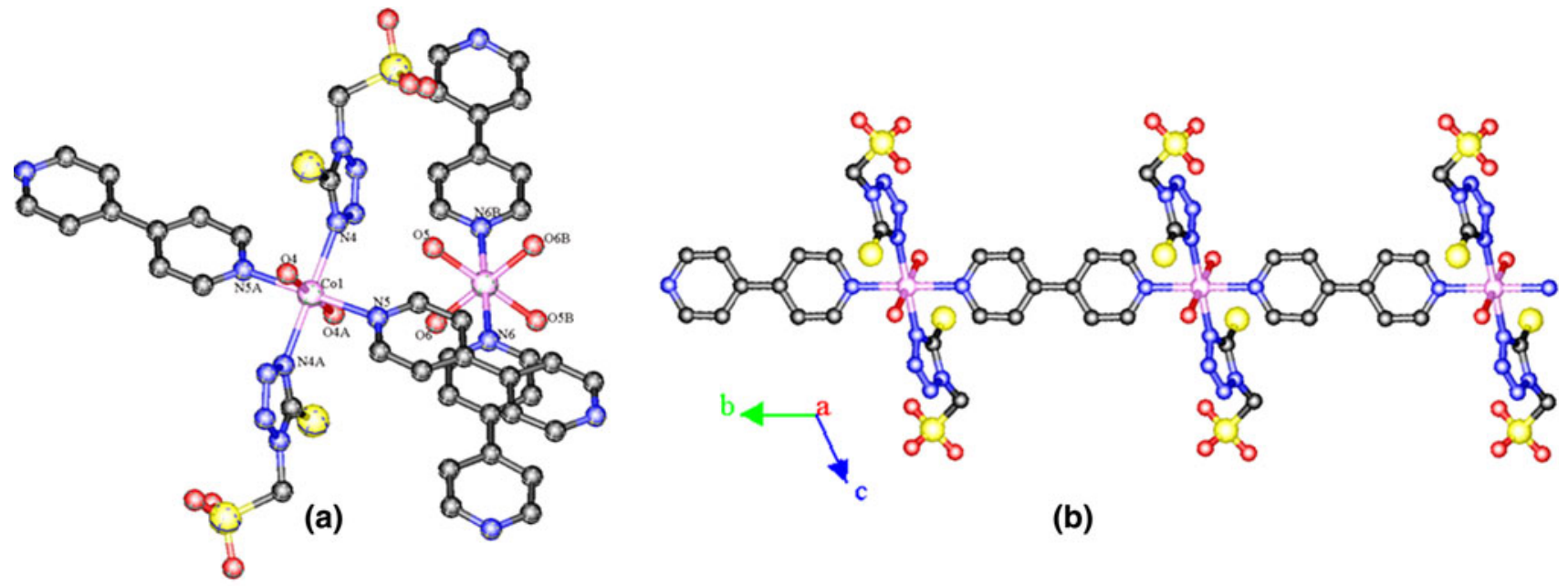

(b)
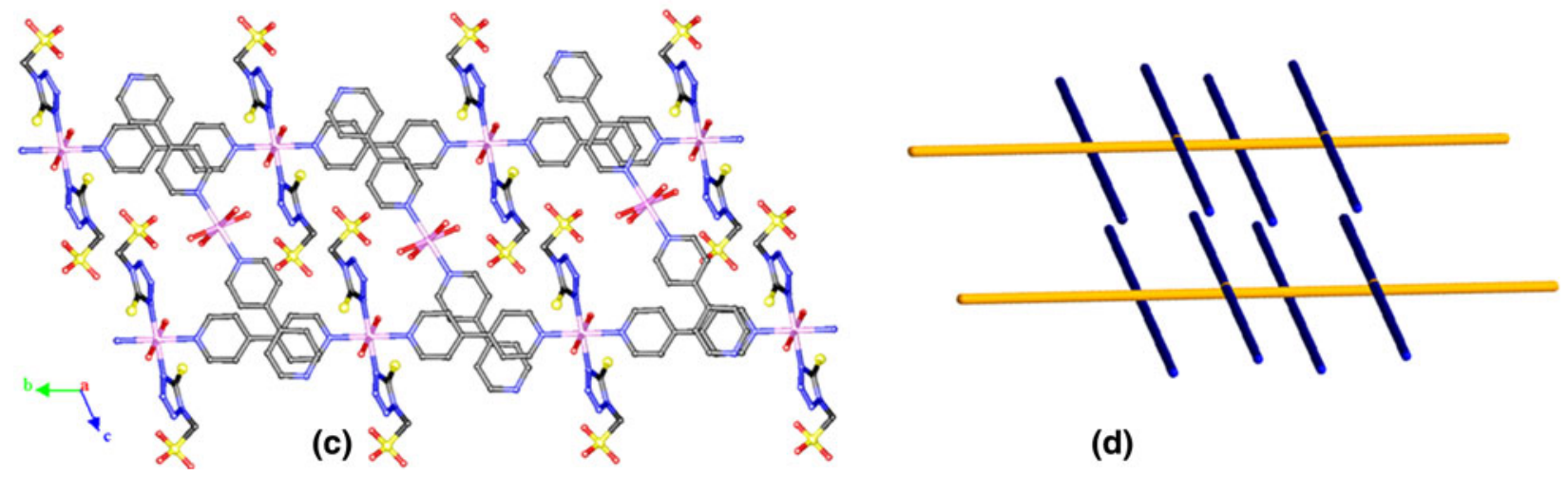

(d)

Fig. 4 a View of the coordination environment of the Co(II) center in 4. Symmetry codes: $A$ : $-x+1,-y+1,-z ; B:-x+2,-y$, $-z+1$. b View of the 1D infinite chain of Co1 along the $b$ axis. c Stacked plot of 4 with the 1D chains of $\mathrm{Co} 1$ and free $\mathrm{Co} 2$ units. d A schematic illustration of the packing of 4. Symmetry codes: $(A)$ $-x+1,-y+1,-z ;(B) x, y-1, z ;(C)-x+2,-y,-z ;(D) x+1$, $y-1, z ;(E) x+1, y, z ;(F)-x+1,-y+1,-z+1 ;(G) x, y+1$, $z ;(H)-x+1,-y+2,-z+1$ 
Cyclic voltammetry

The cyclic voltammogram of $\mathbf{3}$ was measured with a conventional three-electrode cell in aqueous solution with complex concentration of $1.0 \times 10^{-5} \mathrm{~mol} \mathrm{~L}^{-1}$, as shown in Fig. $6 \dagger$. Measurements were carried out at room temperature by scanning from -0.600 to $+1.400 \mathrm{~V}$ at different scan rates. The $\mathrm{CV}$ shows an oxidation peak at $0.444 \mathrm{~V}$ with the scan rate of $50 \mathrm{mV} \mathrm{s}^{-1}$, while there is no corresponding reduction wave. As the scan rate is increased to 80 and $100 \mathrm{mV} \mathrm{s}^{-1}$, the anodic peak appears at 0.479 and $0.567 \mathrm{~V}$, respectively. Again, no corresponding cathodic wave was observed, showing that the electrochemical behavior of the $\mathrm{Zn}(\mathrm{II}) / \mathrm{Zn}(\mathrm{I})$ redox couple is irreversible [30].

\section{Conclusion}

Four new complexes have been constructed from mixed $\mathrm{mtms}$ and bpy ligands. The 2D pillared-layer structure of $\mathbf{1}$ is obtained with carboxylato groups, while complexes $\mathbf{2 , 3}$, and the host structure $\mathbf{4}$ all exhibit 1D infinite chain structures. The results demonstrate that coordinated anions can increase the dimensionality of the crystal structures, while uncoordinated anions can propagate the architectures through hydrogen bonding and $\pi-\pi$ stacking interactions. The $\mathrm{mtms}$ ligand shows four different coordination modes in the four complexes. The varied coordination modes of the neutral rigid linear bpy ligand (bridging coordination, terminal coordination, hydrogen bond, and $\pi-\pi$ stacking) found in this study proves that it is an excellent building block in constructing novel hybrid frameworks. In summary, for the complexes 1-4 described in this paper, we can see that the properties of the anion, mtms, and bpy ligands all help to determine the final coordination architectures.

\section{Supplementary Information}

CCDC 929454-929457 contain the supplementary crystallographic data for complexes 1-4, respectively. These data can be obtained free of charge from the Cambridge Crystallographic Data Centre via www.ccdc.cam.ac.uk/ data_request/cif.

Acknowledgments We gratefully acknowledge the National Nature Science Foundation of China (Nos. 21101035 and 21061002), Guangxi Natural Science Foundation of China (2010GXNSFF 013001,2012GXNSFAA053035, and 2012GXNSFBA053017), the Foundation of Key Laboratory for Chemistry and Molecular Engineering of Medicinal Resources (CMEMR2011-20), and the Nature Science Foundation of Guangxi Normal University.

Open Access This article is distributed under the terms of the Creative Commons Attribution License which permits any use, distribution, and reproduction in any medium, provided the original author(s) and the source are credited.

\section{References}

1. Anderson S, Anderson HL, Sanders JKM (1993) Acc Chem Res 26:469-475

2. Beer PD, Gale PA (2001) Angew Chem 113:502-532

3. Tseng TW, Luo TT, Chen CC, Su CC, Chi KM, Lu KL (2013) Cryst Growth Des 13:510-517

4. Yin PX, Zhang J, Li ZJ, Qin YY, Cheng JK, Zhang L, Lin QP, Yao YG (2009) Cryst Growth Des 9:4884-4896

5. Lassig D, Lincke J, Moellmer J, Reichenbach C, Moeller A, Glaser R, Kalies G, Cychosz KA, Thommes M, Staudt R, Krautscheid H (2011) Angew Chem Int Ed 50:10344-10348

6. Zheng ST, Bu JT, Li YF, Wu T, Zuo F, Feng PY, Bu XH (2010) J Am Chem Soc 132:17062-17064

7. Millange F, Medina MI, Guillou N, Férey G, Golden KM, Walton RI (2010) Angew Chem Int Ed 49:763-766

8. Hao HM, Huang FP, Bian HD, Yu Q, Sun XL, Liang H (2011) Polyhedron 30:2099-2105

9. Matyáš R, Pachman J (2013) Primary explosives. Springer, Berlin, pp 227-254

10. Erkhitueva EB, Egorov DM, Dogadina AV, Khramchikhin AV, Ionin BI (2012) J Gen Chem 82(12):2011-2012

11. Akrivos PD (2001) Coord Chem Rev 213:181-210

12. Tamilselvi A, Mugesh G (2011) Inorg Chem 50:749-756

13. Biswas N, Thomas S, Sarkar A, Mukherjee T, Kapoor S (2009) J Phys Chem C 113:7091-7100

14. Li Y, Wang CQ, Bian HD, Huang FP, Liang H, Yu Q (2012) J Coord Chem 65:3665-3673

15. Tamilselvi A, Mugesh G (2011) Inorg Chem 50:749-756

16. Biswas N, Thomas S, Sarkar A, Mukherjee T, Kapoor S (2009) J Phys Chem C 113:7091

17. Yu Q, Huang FP, Yang ZM, Jin J, Bian HD, Liang H (2012) Polyhedron 33:203-208

18. Klinowski J, Paz FAA, Silva P, Rocha J (2011) Dalton Trans 40:321

19. Mondal R, Basu T, Sadhukhan D, Chattopadhyay T, Bhunia M (2009) Cryst Growth Des 9:1095-1105

20. De Melo ACC, De Amorim IF, Cirqueira ML, Martins FT (2013) Cryst Growth Des 13:1558-1569

21. Huang FP, Yu Q, Bian HD, Yan SP, Liang H (2008) Polyhedron 27:3160-3166

22. Huang FP, Li HY, Tian JL, Gu W, Jiang LM, Yan SP, Liao DZ (2009) Cryst Growth Des 7:3191-3196

23. Sheldrick GM (1997) SHELXL-97, program for X-ray crystal structure refinement. GÖttingen University, Germany

24. Wang XJ, Liu YH, Xu CY, Hou HW, Fan YT (2012) Cryst Growth Des 12:2435-2444

25. Jun H (2005) J Mol Struct 752:166-169

26. Sun L, Ma L, Cai JB, Liang L, Deng H (2012) Cryst Eng Comm 14:890-898

27. Li Q, Fu ML, Liu X, Guo GC, Huang JS (2006) Inorg Chem Comm 9:767-771

28. Li XP, Zhang JY, Pan M, Zheng SR, Liu Y, Su CY (2007) Inorg Chem 46:4617

29. Gao JY, Wang N, Xiong XH, Chen CJ, Xie WP (2013) Cryst Eng Comm 15:3261-3270

30. Odabas Z, Kara H, Özkaya AR, Bulut M (2012) Polyhedron 39:38-47 